\title{
Can a Science, Technology, Engineering, and Mathematics (STEM) Approach Enhance Students' Mathematics Performance?
}

\author{
Suik Fern Kong ${ }^{1}$ and Mohd Effendi Ewan Mohd Matore ${ }^{2, *(\mathbb{D})}$ \\ 1 Faculty of Education, Universiti Kebangsaan Malaysia (UKM), Bangi 43600, Malaysia; \\ p99986@siswa.ukm.edu.my \\ 2 Research Centre of Education Leadership and Policy, Faculty of Education, Universiti Kebangsaan \\ Malaysia (UKM), Bangi 43600, Malaysia \\ * Correspondence: effendi@ukm.edu.my
}

check for

updates

Citation: Kong, S.F.; Mohd Matore, M.E.E. Can a Science, Technology, Engineering, and Mathematics (STEM) Approach Enhance Students' Mathematics Performance? Sustainability 2022, 14, 379.

https://doi.org/10.3390/su14010379

Academic Editors: Anita Tabacco, Gavin Duffy, Alicia García-Holgado, Rachel Riedner and Marc A. Rosen

Received: 11 October 2021

Accepted: 22 December 2021

Published: 30 December 2021

Publisher's Note: MDPI stays neutral with regard to jurisdictional claims in published maps and institutional affiliations.

Copyright: (c) 2021 by the authors. Licensee MDPI, Basel, Switzerland. This article is an open access article distributed under the terms and conditions of the Creative Commons Attribution (CC BY) license (https:// creativecommons.org/licenses/by/ $4.0 /)$.

\begin{abstract}
The STEM approach is a student-centred teaching and learning process that involves an inquiry process in problem-solving questions. This study was conducted to examine the effectiveness of the STEM approach in enhancing students' mathematics performance. The study used a quasiexperimental design of unbalanced groups through the pre-test and post-test for treatment and control groups. The instrument included a set of questionnaires on student attitudes towards STEM implementation and the three-dimensional geometric shapes achievement test. The research samples included 14-year-old students from one of the private secondary schools in Kuching, which involved 68 students who were selected using purposive sampling. The results showed that student attitudes towards the implementation of the STEM approach were at a moderate level. In addition, the results illustrated a significant and moderate difference in mathematics performance between students who participated in the STEM approach and the conventional method using pre-test and post-test. The mean score of the post-test performance for the STEM approach was higher compared to the mean score of post-test performance for the conventional method. The results of the study demonstrated that the implementation of the STEM approach that involved both inquiry-based learning and problem-based learning was effective and able to improve the students' academic performance. This can help teachers to vary their teaching and learning methods by increasing student interactions and engagement. Improvements can be made in the future by adding more research samples to expand the context of the study and prolong the treatment duration. Researchers can also add research variables in future studies by examining student interests and motivations towards the STEM approach.
\end{abstract}

Keywords: STEM approach; performance; mathematics; quasi-experimental; three-dimensional geometric shapes

\section{Introduction}

STEM was first introduced by the National Science Foundation (NSF) in the year 2001 in the United States. Subsequently, STEM was introduced in Malaysia's national education in 2013 through the Malaysia Education Development Plan 2013-2025. STEM integration in education can raise students' awareness of the importance of the engineering field regarding comprehension, the provision of engineering design, and the enhancement of technology literacy by venturing into this field. The implementation of STEM in education also encourages students to think critically and creatively whilst increasing student motivation [1]. Meanwhile, LaForce et al. [2] found that the use of problem-based learning by integrating STEM elements could foster student attitudes and interests in venturing into STEM fields.

This study highlighted some issues on the use of the conventional method in the teaching and learning process, which practices fewer group activities and does not emphasise the value of cooperation among students. Meanwhile, teachers are more likely to 
emphasise theoretical understanding than concepts [3,4]. In terms of performance, based on the results in Trends in International Mathematics and Science Study (TIMSS) and the Programme for International Student Assessment (PISA), the level of student achievement in mathematics is still unsatisfactory [5]. Teacher-centred learning as practiced currently will result in students becoming less engaged in the teaching and learning process [6].

The STEM approach focuses on teaching and learning in problem-solving with a student-centred inquiry process [7]. Student-centred learning can guide and help students to highlight their talent in problem-solving based on the inquiry process. As argued by Ugras [8], studies related to STEM education are still lacking and the systematic review of Wahono et al. [9] shows that Asian countries only have 86 articles with keywords related to the effects of STEM on education. In other words, studies related to the effectiveness of STEM in the teaching and learning process are still inadequate to address the arising issues. Moreover, previous studies, such as Lin et al. [10] and Sahin and Top [11], have only focused on inquiry-based learning or project-based learning. In countries such as Taiwan and Texas, studies were conducted on the effectiveness of STEM but were limited to one learning method only $[10,11]$.

As a result of such issues, this study was conducted to determine whether the use of the STEM approach could improve students' mathematics performance in the teaching and learning process in comparison with the conventional method.

Hence, this study had the following research objectives:

i. To identify student attitudes towards the implementation of the STEM approach.

ii. To identify the differences in mathematics performance between students who participated in the STEM approach and the conventional method.

Overall, this study was conducted to examine the effectiveness of the STEM approach in enhancing the mathematics performance of 14-year-old students using the threedimensional geometric shapes topic. The STEM approach in the context of this study entails the use of inquiry-based learning and problem-based learning so that the students could actively interact and engage in learning. Furthermore, the STEM approach was compared with the conventional method to obtain a more effective method in the teaching and learning process. Indeed, the teaching and learning process in the classroom should be done using more effective methods to improve student learning performance.

\section{Literature Review}

The history and development of STEM were derived from science, mathematics, engineering, and technology, which was known as SMET and converted to STEM by the National Science Foundation (NSF). Subsequently, STEM is also combined with art, constituting science, technology, engineering, arts, and mathematics [12]. However, the interdisciplinary combination of STEM with arts elements has not been applied in the Malaysian education field. Edy Hafizan et al. [13] stated that the application of STEM in Malaysian education is oriented towards developing the country's economy and training the younger generation to take part in STEM-related employment sectors. Therefore, education using STEM was implemented through lower secondary education to prepare students to encounter global challenges [14].

STEM education can be defined in different contexts. According to Wong and Kamisah [15], the STEM approach emphasises the elements of 21st-century learning that are capable of collaborating, communicating, as well as thinking critically and creatively. Furthermore, the ultimate goal of the STEM approach is to enable teachers and students to know and recognise the importance of knowledge and practice to be applied in the teaching and learning process [16]. Meanwhile, English [17] stated that STEM education involves critical thinking, the problemsolving and inquiry process, teamwork, design processing, and engineering elements.

Conventional methods are the more frequently used teaching methods in comparison with the STEM approach. Comparisons were made between treatment groups, which include students who participated in the adapted learning methods, and the control groups, which include students who participated in the conventional methods. Evidently, students 
in the treatment groups were more motivated and confident to pursue learning than those in the control groups using conventional methods $[4,18,19]$. The use of conventional methods was also found to yield low student engagement and achievement $[6,20]$. Hence, based on the literature review, conventional methods should integrate with other learning methods to enhance student motivation and achievement in mathematics.

Furthermore, comparisons between studies on the STEM approach conducted locally and internationally were also detailed. International studies related to the STEM approach showed that students who pursued this type of learning achieved better than those who participated in the conventional learning methods [21]. The studies also found that the STEM approach using project-based learning was effective and gained positive feedback from students [22-24]. Moreover, Ardianti et al. [25] and Seshaiyer et al. [26] found that the implementation of the STEM approach can train students to think creatively and critically, which improves their problem-solving ability. In terms of local studies in Malaysia, problembased learning and cooperative learning can improve students' life and achievement [27,28]. Based on these comparisons, students who participated in STEM learning are more skilled and capable compared with those who only participated in the conventional learning methods.

STEM integration in education involves social constructivism theory and behaviourism theory. The social constructivism theory comprises STEM elements, problem-based learning, and inquiry-based learning [29]. While McKinley [30] and Vygotsky [31] interpreted the exploration process as the result of interaction, student attitudes can be attributed to the behaviourism theory, where a behaviour affects a person without engaging in thought functions [32]. In the context of this study, the social constructivism theory refers to learning using the inquiry process, which is the exploration of gaining knowledge through interaction.

In addition, student attitudes towards the STEM approach have evidenced a significant relationship [33]; thus, the relationship between student attitudes and the STEM teaching and learning method can be further examined. Subsequently, the use of an inquiry-based learning model can foster student attitudes towards the integration of STEM projects [11]. Student attitudes towards a particular learning method are crucial and continuable if the students have a positive attitude because this enables STEM integration in education to be more beneficial and further enhances the students' interaction ability.

A literature review on the STEM approach allows for the knowledge of STEM development in education from time to time. Overall, STEM education is very helpful in the self-development of students such that the students will know and acquire knowledge through self-exploration and observation. STEM education also helps students to fathom and apply their knowledge. However, STEM education takes longer compared to conventional methods in teaching and learning because STEM education needs to provide space and opportunity for students to explore and observe compared to conventional methods that only focus on memorising and acquiring knowledge from instructors or teachers. Ramli [27] showed that the STEM approach yielded no differences compared to conventional methods. Similarly, research conducted by Mohd Ayub et al. [19] also showed that the STEM approach was unfavorable and yielded no differences compared to conventional methods.

Since the study conducted by Ramli [27] was merely based on cooperative-based learning, the present study combining inquiry-based learning methods and problem-based learning has the potential to improve the level of achievement in mathematics. Due to different teaching methods and very little empirical evidence related to the effectiveness of STEM in inquiry-based learning and problem-based learning, there is a clear gap that could be filled by conducting this study. Hence, this study was conducted to examine the effectiveness of the STEM approach in enhancing students' mathematics performance. A study by Lin et al. [10] in Taiwan used inquiry-based learning to test the effectiveness of STEM education among students aged 12 to 13 years old for engineering and technologyrelated fields, but the findings [10] showed no statistical difference between STEM learning 
methods and conventional methods. However, Sahin and Top [11] conducted a study in Texas by using STEM in project-based learning method for science students aged 16 to 17 years old and the results [11] showed that STEM education can improve student performance and achievement. Thus, the present study was conducted to examine the effectiveness of STEM among 14-year-old students in mathematics using inquiry-based and problem-based learning methods.

Most studies showed that the implementation of STEM in education that includes inquiry-based learning, problem-based learning, project-based learning, and others can help to improve student performance. Thus, in future studies, the expansion of topics for learning and the number of research samples are necessary to demonstrate the effectiveness of these studies. The literature has also deliberated STEM development in education, as well as the studies related to the STEM approach. References from past studies were also related to STEM and the implementation of STEM elements in education. The outcome of the literature review can provide continuity to examine the effectiveness of the STEM approach in improving the level of mathematics performance of 14-year-old students.

\section{Materials and Methods}

The research design was quasi-experimental through a pre-test and post-test for unbalanced groups involving two research groups: treatment and control [34]. The treatment group was provided with teaching and learning through the STEM approach, while the control group received the conventional method. The research samples were selected from St. Joseph's Private Secondary School, Kuching, which involved 68 students overall. The students were divided into two groups, each comprising 34 students based on the results and scores of the students' previous mathematics test. The research samples were selected by using convenience sampling. According to Etikan et al. [35], the convenience sampling technique can be conducted in quantitative research. Kumar [36] also mentioned that convenience sampling is easily accessible for students. Even so, the researchers chose different classes and evenly divided the students according to the results of the previous mathematics exam.

This study used two instruments, namely, the three-dimensional geometric shapes achievement test and questionnaires in measuring student attitudes towards the STEM approach. The achievement test consists of 15 subjective questions in the form of problemsolving with a total score of 54. Questions for the achievement test were taken from workbooks, reference books, and textbooks, while the questionnaires were adapted from a study by Suprapto [33], consisting of four sections that comprise science, mathematics, technology, engineering, and STEM. The instrument given to the students to assess their attitudes towards the STEM approach consisted of 25 items, as shown in Appendix A, Table A1.

The level of instrument reliability for both instruments was assessed using Cronbach's alpha value $(\alpha)$, which refers to the reliability coefficient used to test the internal consistency of the research instrument [37]. The interpretations for Cronbach's alpha value and internal consistency are shown in Table 1. Cronbach's alpha value ranges from 0 to 1 ; an $\alpha$ value that is more than 0.9 denotes an excellent internal consistency level, while an $\alpha$ value that is less than 0.6 denotes a poor internal consistency level [38].

Table 1. Cronbach's alpha value and internal consistency.

\begin{tabular}{cc}
\hline Cronbach's Alpha Value $(\alpha)$ & Internal Consistency \\
\hline$\alpha \geq 0.9$ & Excellent \\
$0.8 \leq \alpha<0.9$ & Good \\
$0.7 \leq \alpha<0.8$ & Acceptable \\
$0.6 \leq \alpha<0.7$ & Questionable \\
$\alpha<0.6$ & Poor \\
\hline
\end{tabular}


Table 2 shows the method of data analysis for the research objectives. The acquired research data were analysed using SPSS version 26. This study employed descriptive statistics and inferential statistics. Specifically, the study used mean and standard deviation descriptive statistics for the questions on student attitudes towards the implementation of the STEM approach. Subsequently, a paired sample $t$-test was the inferential method used in this study to examine the differences in mathematics performance between the students who participated in the STEM approach and the conventional method.

Table 2. Data analysis.

\begin{tabular}{ccc}
\hline Objective & Hypothesis & Analysis \\
\hline $\begin{array}{c}\text { To identify student attitudes } \\
\text { towards the implementation } \\
\text { of the STEM approach }\end{array}$ & - & $\begin{array}{c}\text { Descriptive measurements of } \\
\text { central tendency and } \\
\text { variance }\end{array}$ \\
\hline $\begin{array}{c}\text { To identify the differences in } \\
\text { mathematics performance } \\
\text { between students who } \\
\text { participated in the STEM } \\
\text { approach and the }\end{array}$ & $\begin{array}{c}\text { There is no significant } \\
\text { difference in mathematics } \\
\text { performance between } \\
\text { students who participated in } \\
\text { the STEM approach and the } \\
\text { conventional method }\end{array}$ & Paired sample $t$-test \\
\hline
\end{tabular}

Figure 1 illustrates the research procedure undertaken in this study. The instrument of achievement test for the three-dimensional geometric shapes topic was validated by five experts from the fields of mathematics, language, as well as psychometric and evaluation. Subsequently, the researchers obtained permission from St. Joseph's Private Secondary School, Kuching, to collect data from the respondents. Finally, the selected research samples were divided into two groups, namely, the treatment group and the control group according to their previous achievement test scores.

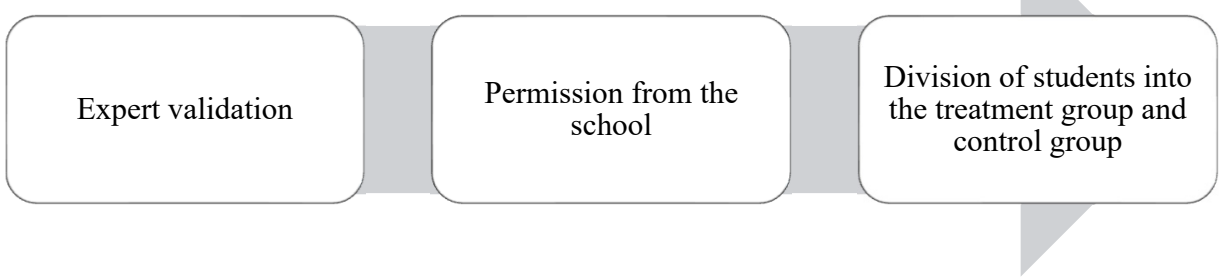

Figure 1. Research framework.

The study was conducted using the topic of three-dimensional geometry shapes because the field of geometry is one of the topics examined in international assessments, namely, TIMSS and PISA, besides improving student achievement in answering problemsolving questions in the form of higher-order thinking skills (HOTS). Furthermore, research on the topic of three-dimensional geometric shapes using STEM-based teaching approaches is still very limited. A previous study examined the topic of algebra and used a STEM-based teaching approach that uses flipped classrooms compared with conventional methods and the results showed that the STEM-based teaching approach demonstrated a significant improvement in the students' academic achievement compared with conventional methods. However, the study only focused on the topic of algebra [39], while the present study was conducted to examine the effectiveness of a STEM-based teaching approach in problemsolving for the topic of three-dimensional geometric shapes in the subject of mathematics. Figure 2 displays the application of the STEM approach in the teaching and learning process. The students were divided into two groups, namely, the treatment group and the control group. In phase 1, the students sat for a pre-test and then participated in the prescribed learning method in phase 2 . The treatment group engaged in the STEM learning method, 
while the control group engaged in the conventional learning method. Subsequently, in phase 3, students in both groups sat for a post-test after the prescribed learning periods had ended. Finally, in phase 4, students in the treatment group were asked to answer the questionnaires.

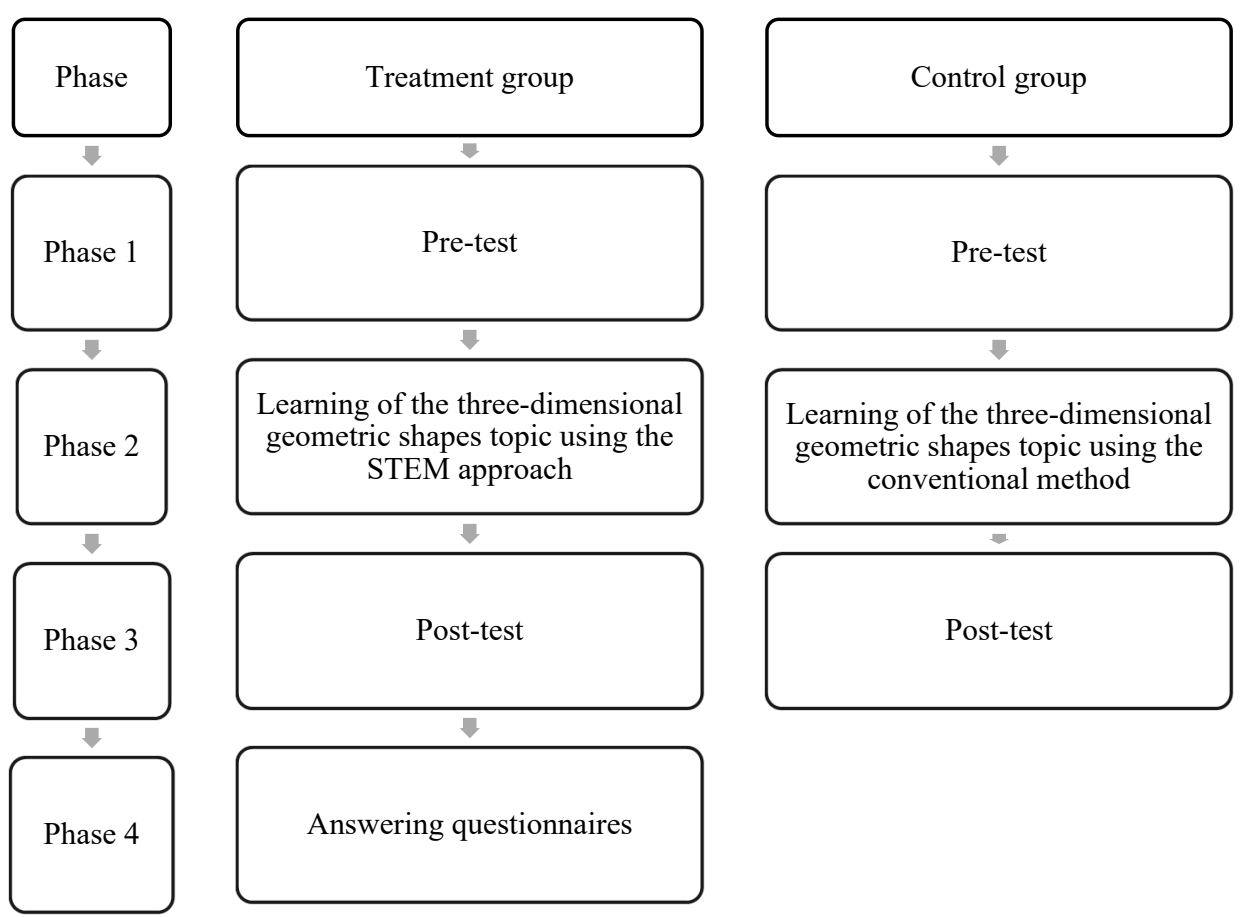

Figure 2. Method used to conduct the research.

The conventional method implemented in this study was teacher-centred. In this regard, the teachers gave assignments to the students and the learning sessions were conducted with minimal teacher-student interactions. Furthermore, the teaching and learning process for the conventional method was carried out without any assistance of technological tools, such as computers and projectors. Hence, this was carried out using whiteboards and textbooks when studying the topic of three-dimensional geometric shapes.

The teaching and learning process of the STEM approach entailed inquiry-based and problem-based learning methods. The STEM approach activity required the students to design and build a dream house using three-dimensional geometric shapes that they had learnt, such as cuboids, cylinders, and cones, which could increase their understanding and thinking skills with regard to problem-solving questions. Figure 3 demonstrates the instructions and steps taken for the students to complete the assigned activity.

The difference between the STEM approach and the conventional method is that the former involves students working in groups to complete assignments, while the latter only focuses on individual learning. In addition, the STEM approach also involves more interactive activities by asking the students to build a dream house using the three-dimensional geometric shapes that they had learnt to increase their problem-solving level regarding HOTS questions. Furthermore, the STEM approach allowed the students to think critically through inquiry-based learning, which allowed them to learn and understand the formulas for the topic of three-dimensional geometric shapes instead of encouraging them to memorise those formulas as was done in the conventional method. Thus, the use of the STEM approach in the teaching and learning process encourages students to interact and fosters the value of collaboration between students and their ability to think critically. 
Dividing students into a group of three
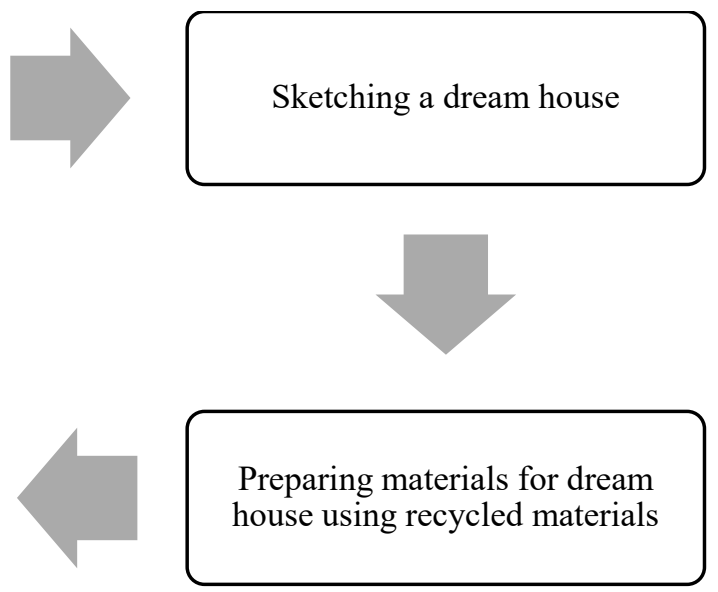

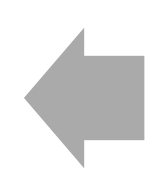

Calculating the surface area and volume of the dream house

Figure 3. STEM approach activity process.

\section{Results}

The collected data were analysed in the research findings section and all of the collected data were examined in terms of reliability and normality prior to the analysis. Overall, this study comprised two main questions to be analysed and discussed in detail.

Specifically, the collected data were analysed using SPSS (software version 26.0, IBM Corporation, New York, NY, USA). Based on the reliability test results for the data based on Cronbach's alpha coefficient value, the instruments of the three-dimensional geometric shapes achievement test and student attitudes towards the STEM approach were 0.867 and 0.827 , respectively, which are considered good. Table 3 shows the results of Levene's homogeneity of variance test that validates whether the items had a sample bias. In this study, Levene's test was used to assess the equality of variances for a variable calculated for two groups (gender).

Table 3. Levene's homogeneity of variance test (sample bias testing).

\begin{tabular}{|c|c|c|c|c|c|}
\hline \multirow{2}{*}{\multicolumn{2}{|c|}{ Test Score }} & \multicolumn{2}{|c|}{$\begin{array}{c}\text { Levene's Test for } \\
\text { Equality of } \\
\text { Variance }\end{array}$} & \multirow[t]{2}{*}{$t$} & \multirow[t]{2}{*}{$\mathbf{d f}$} \\
\hline & & $\mathbf{F}$ & Sig. & & \\
\hline Pre-test (STEM) & $\begin{array}{c}\text { Equal variance } \\
\text { assumed } \\
\text { Equal variance not } \\
\text { assumed }\end{array}$ & $\begin{array}{c}2.269 \\
-\end{array}$ & $\begin{array}{c}0.142 \\
-\end{array}$ & $\begin{array}{c}-1.233 \\
-\end{array}$ & $\begin{array}{r}32 \\
-\end{array}$ \\
\hline Post-test (STEM) & $\begin{array}{c}\text { Equal variance } \\
\text { assumed } \\
\text { Equal variance not } \\
\text { assumed }\end{array}$ & 0.744 & 0.395 & $\begin{array}{c}-0.709 \\
-\end{array}$ & 32 \\
\hline $\begin{array}{l}\text { Student attitudes } \\
\text { towards STEM }\end{array}$ & $\begin{array}{c}\text { Equal variance } \\
\text { assumed } \\
\text { Equal variance not } \\
\text { assumed }\end{array}$ & 0.441 & 0.511 & -0.507 & 32 \\
\hline
\end{tabular}

Note: $\mathrm{df}$ - degree of freedom.

The results indicated that the p-value was more than 0.05 for the items in STEM and student attitudes towards STEM. This means that Levene's test was statistically not significant since $p>0.05$ with equal variance assumed for the samples. The assumption of homogeneity of variance is an assumption of the independent samples $t$-test stating that all comparison groups have the same variance. Moreover, Levene's test showed no significant difference between gender (male and female students) for the STEM pre-test score $\left(t_{32}=-1.233, p=0.142\right)$, STEM post-test score $\left(t_{32}=-0.709, p=0.395\right)$, and student 
attitudes towards STEM $\left(t_{32}=-0.507, p=0.511\right)$. These results evidenced an early sign that the items did not have any sample bias according to gender (STEM-unbiased in order to evaluate the results).

Meanwhile, the normality of the data was analysed using the Shapiro-Wilk test because the research samples involved fewer than 50 respondents. The normality test results for the STEM approach and conventional method post-tests were 0.081 and 0.056 , respectively, while student attitudes towards the STEM approach were recorded at 0.267 . The normality of the data exceeded 0.05 , suggesting that the data exceeded the significant level. Hence, the data were considered normally distributed and had a good reliability level.

\subsection{Objective 1: To Identify Student Attitudes towards the Implementation of STEM Approach}

Table 4 exhibits a frequency summary and percentages for student attitudes towards the implementation of the STEM approach. Descriptive statistics were used to assess the students' attitudes towards the STEM approach based on the mean of overall items in the questionnaires. The interpretation of mean values consisted of three levels: low, moderate, and high. Layang and Mahamod [40] divided mean values according to three levels, where the low-level ranged from 1.00 to 2.66, the moderate level ranged from 2.67 to 3.66 , and the high-level ranged from 3.67 to 5.00. Based on the analysis results, the mean value for the overall instruments was 3.61, while the standard deviation was found to be 0.56 . In reference to the average mean value, student attitudes towards the implementation of the STEM approach were at a moderate level.

Table 4. Frequency summary and percentage for student attitudes towards the implementation of the STEM approach.

\begin{tabular}{|c|c|c|c|c|c|c|c|c|c|c|}
\hline \multirow{2}{*}{ Item Code } & \multicolumn{2}{|c|}{$\begin{array}{c}\text { Strongly Agree } \\
\text { (SA) }\end{array}$} & \multicolumn{2}{|c|}{ Agree (A) } & \multicolumn{2}{|c|}{ Uncertain (U) } & \multicolumn{2}{|c|}{ Disagree (D) } & \multicolumn{2}{|c|}{$\begin{array}{c}\text { Strongly } \\
\text { Disagree (SD) }\end{array}$} \\
\hline & $\mathbf{F}$ & $\%$ & $\mathbf{F}$ & $\%$ & $\mathbf{F}$ & $\%$ & $\mathbf{F}$ & $\%$ & $\mathbf{F}$ & $\%$ \\
\hline $\mathrm{S} 1$ & 3 & 8.8 & 16 & 47.1 & 12 & 35.3 & 3 & 8.8 & 0 & 0 \\
\hline S2 & 6 & 17.6 & 16 & 47.1 & 9 & 26.5 & 3 & 8.8 & 0 & 0 \\
\hline S3 & 8 & 23.5 & 18 & 52.9 & 6 & 17.6 & 0 & 0 & 2 & 5.9 \\
\hline $\mathrm{S} 4$ & 7 & 20.6 & 15 & 44.1 & 8 & 23.5 & 4 & 11.8 & 0 & 0 \\
\hline S5 & 8 & 23.5 & 11 & 32.4 & 13 & 38.2 & 2 & 5.9 & 0 & 0 \\
\hline S6 & 7 & 20.6 & 8 & 23.5 & 16 & 47.1 & 3 & 8.8 & 0 & 0 \\
\hline M1 & 7 & 20.6 & 14 & 41.2 & 9 & 26.5 & 3 & 8.8 & 1 & 2.9 \\
\hline M2 & 1 & 2.9 & 11 & 32.4 & 12 & 35.3 & 8 & 23.5 & 2 & 5.9 \\
\hline M3 & 1 & 2.9 & 10 & 29.4 & 16 & 47.1 & 6 & 17.6 & 1 & 2.9 \\
\hline M4 & 2 & 5.9 & 9 & 26.5 & 17 & 50.0 & 5 & 14.7 & 1 & 2.9 \\
\hline M5 & 1 & 2.9 & 13 & 38.2 & 16 & 47.1 & 4 & 11.8 & 0 & 0 \\
\hline M6 & 2 & 5.9 & 10 & 29.4 & 18 & 52.9 & 4 & 11.8 & 0 & 0 \\
\hline TE1 & 6 & 17.6 & 14 & 41.2 & 11 & 32.4 & 3 & 8.8 & 0 & 0 \\
\hline TE2 & 7 & 20.6 & 13 & 38.2 & 12 & 35.3 & 2 & 5.9 & 0 & 0 \\
\hline TE3 & 5 & 14.7 & 14 & 41.2 & 9 & 26.5 & 5 & 14.7 & 1 & 2.9 \\
\hline TE4 & 4 & 11.8 & 13 & 38.2 & 12 & 35.3 & 4 & 11.8 & 1 & 2.9 \\
\hline TE5 & 5 & 14.7 & 12 & 35.3 & 13 & 38.2 & 3 & 8.8 & 1 & 2.9 \\
\hline TE6 & 2 & 5.9 & 3 & 8.8 & 55 & 64.7 & 4 & 11.8 & 3 & 8.8 \\
\hline STEM1 & 6 & 17.6 & 14 & 41.2 & 10 & 29.4 & 2 & 5.9 & 2 & 5.9 \\
\hline STEM2 & 8 & 23.5 & 20 & 58.5 & 5 & 14.7 & 1 & 2.9 & 0 & 0 \\
\hline STEM3 & 8 & 23.5 & 19 & 55.9 & 5 & 14.7 & 2 & 5.9 & 0 & 0 \\
\hline STEM4 & 13 & 38.2 & 18 & 52.9 & 2 & 5.9 & 1 & 2.9 & 0 & 0 \\
\hline STEM5 & 12 & 35.2 & 14 & 41.2 & 6 & 17.6 & 2 & 5.9 & 0 & 0 \\
\hline STEM6 & 10 & 29.4 & 19 & 55.9 & 4 & 11.8 & 1 & 2.9 & 0 & 0 \\
\hline STEM7 & 8 & 23.5 & 10 & 29.4 & 12 & 35.3 & 3 & 8.8 & 1 & 2.9 \\
\hline
\end{tabular}

Note: F-frequency, S—science; M-mathematics; TE—technology and engineering; STEM—science, technology, engineering, and mathematics. 
4.2. Objective 2: To Identify the Differences in Mathematics Performance between Students Who Participated in the STEM Approach and the Conventional Method

The pre-test results for the conventional method and STEM approach according to the total score of each participant are indicated in Table 5. Students who scored more than 50\% for the conventional method and STEM approach pre-tests constituted two and six students, respectively. The passing score for a test according to the Ministry of Education Malaysia (MOE) is $50 \%$, which is deemed a satisfactory level. The research samples were given a treatment period of approximately a week using a STEM learning method or a conventional learning method. The STEM learning method or STEM approach engaged the students in building a dream house using three-dimensional geometric shapes and applying the surface area and volume formulae for each shape. Meanwhile, the conventional method included engaging in classroom learning that was more oriented to the memorisation of the three-dimensional geometric shapes formulae.

Table 5. Pre-test scores for conventional method and STEM approach.

\begin{tabular}{|c|c|c|c|c|c|}
\hline \multicolumn{3}{|c|}{$\begin{array}{c}\text { Conventional Method } \\
\text { Pre-Test Scores }\end{array}$} & \multicolumn{3}{|c|}{$\begin{array}{l}\text { STEM Approach } \\
\text { Pre-Test Scores }\end{array}$} \\
\hline $\begin{array}{l}\text { Control } \\
\text { Group }\end{array}$ & Score & $\begin{array}{c}\text { Percentage } \\
(\%)\end{array}$ & $\begin{array}{l}\text { Treatment } \\
\text { Group }\end{array}$ & Score & $\begin{array}{c}\text { Percentage } \\
(\%)\end{array}$ \\
\hline 1 & 14 & 26 & 1 & 41 & $76^{*}$ \\
\hline 2 & 19 & 35 & 2 & 12 & 22 \\
\hline 3 & 21 & 39 & 3 & 21 & 39 \\
\hline 4 & 14 & 26 & 4 & 9 & 17 \\
\hline 5 & 26 & 48 & 5 & 25 & 46 \\
\hline 6 & 6 & 11 & 6 & 4 & 7 \\
\hline 7 & 12 & 22 & 7 & 14 & 26 \\
\hline 8 & 8 & 15 & 8 & 28 & $52 *$ \\
\hline 9 & 23 & 43 & 9 & 18 & 33 \\
\hline 10 & 24 & 44 & 10 & 27 & 50 * \\
\hline 11 & 29 & 54 * & 11 & 10 & 19 \\
\hline 12 & 12 & 22 & 12 & 29 & 54 * \\
\hline 13 & 9 & 17 & 13 & 23 & 43 \\
\hline 14 & 6 & 11 & 14 & 19 & 35 \\
\hline 15 & 2 & 4 & 15 & 40 & $74^{*}$ \\
\hline 16 & 8 & 15 & 16 & 18 & 33 \\
\hline 17 & 14 & 26 & 17 & 43 & 80 * \\
\hline 18 & 0 & 0 & 18 & 17 & 31 \\
\hline 19 & 4 & 7 & 19 & 5 & 9 \\
\hline 20 & 28 & $52 *$ & 20 & 1 & 2 \\
\hline 21 & 4 & 7 & 21 & 1 & 2 \\
\hline 22 & 14 & 26 & 22 & 1 & 2 \\
\hline 23 & 3 & 6 & 23 & 15 & 28 \\
\hline 24 & 1 & 2 & 24 & 0 & 0 \\
\hline 25 & 8 & 15 & 25 & 4 & 7 \\
\hline 26 & 8 & 15 & 26 & 23 & 43 \\
\hline 27 & 2 & 4 & 27 & 17 & 31 \\
\hline 28 & 8 & 15 & 28 & 2 & 4 \\
\hline 29 & 1 & 2 & 29 & 19 & 35 \\
\hline 30 & 7 & 13 & 30 & 5 & 9 \\
\hline 31 & 0 & 0 & 31 & 5 & 9 \\
\hline 32 & 2 & 4 & 32 & 2 & 4 \\
\hline 33 & 0 & 0 & 33 & 2 & 4 \\
\hline 34 & 4 & 7 & 34 & 4 & 7 \\
\hline
\end{tabular}

Note: * denotes students who passed the test.

After completing the pre-test, the students were given a post-test to measure their level of understanding after being taught using the different methods. Table 6 presents the total score of each participant for the conventional method and STEM approach post- 
tests. Overall, based on the data, students who scored more than $50 \%$ for the conventional method and the STEM approach constituted 6 and 16 students, respectively.

Table 6. Post-test scores for the conventional method and STEM approach.

\begin{tabular}{|c|c|c|c|c|c|}
\hline \multicolumn{3}{|c|}{$\begin{array}{l}\text { Conventional Method } \\
\text { Post-Test Scores }\end{array}$} & \multicolumn{3}{|c|}{$\begin{array}{l}\text { STEM Approach } \\
\text { Post-Test Scores }\end{array}$} \\
\hline $\begin{array}{l}\text { Control } \\
\text { Group }\end{array}$ & Score & $\begin{array}{c}\text { Percentage } \\
(\%)\end{array}$ & $\begin{array}{l}\text { Treatment } \\
\text { Group }\end{array}$ & Score & $\begin{array}{l}\text { Percentage } \\
(\%)\end{array}$ \\
\hline 1 & 16 & 30 & 1 & 48 & $89 *$ \\
\hline 2 & 24 & 44 & 2 & 16 & 30 \\
\hline 3 & 15 & 28 & 3 & 23 & 43 \\
\hline 4 & 28 & $52 *$ & 4 & 24 & 44 \\
\hline 5 & 27 & $50 *$ & 5 & 25 & 46 \\
\hline 6 & 9 & 17 & 6 & 7 & 13 \\
\hline 7 & 16 & 30 & 7 & 28 & $52 *$ \\
\hline 8 & 15 & 28 & 8 & 39 & $72 *$ \\
\hline 9 & 16 & 30 & 9 & 37 & $69 *$ \\
\hline 10 & 40 & $74 *$ & 10 & 29 & $54 *$ \\
\hline 11 & 33 & $61 *$ & 11 & 26 & 48 \\
\hline 12 & 22 & 41 & 12 & 33 & $61 *$ \\
\hline 13 & 27 & $50 *$ & 13 & 32 & $59 *$ \\
\hline 14 & 11 & 20 & 14 & 38 & $70 *$ \\
\hline 15 & 4 & 7 & 15 & 50 & $93 *$ \\
\hline 16 & 20 & 37 & 16 & 30 & $56^{*}$ \\
\hline 17 & 22 & 41 & 17 & 31 & $57^{*}$ \\
\hline 18 & 1 & 2 & 18 & 48 & 89 * \\
\hline 19 & 3 & 6 & 19 & 30 & $56^{*}$ \\
\hline 20 & 32 & $59 *$ & 20 & 3 & 6 \\
\hline 21 & 5 & 9 & 21 & 4 & 7 \\
\hline 22 & 22 & 41 & 22 & 4 & 7 \\
\hline 23 & 9 & 17 & 23 & 21 & 39 \\
\hline 24 & 6 & 11 & 24 & 3 & 6 \\
\hline 25 & 9 & 17 & 25 & 7 & 13 \\
\hline 26 & 11 & 20 & 26 & 37 & $69 *$ \\
\hline 27 & 6 & 11 & 27 & 35 & $65 *$ \\
\hline 28 & 9 & 17 & 28 & 10 & 19 \\
\hline 29 & 2 & 4 & 29 & 20 & 37 \\
\hline 30 & 7 & 13 & 30 & 9 & 17 \\
\hline 31 & 5 & 9 & 31 & 36 & $67^{*}$ \\
\hline 32 & 7 & 13 & 32 & 15 & 28 \\
\hline 33 & 7 & 13 & 33 & 8 & 15 \\
\hline 34 & 17 & 31 & 34 & 9 & 17 \\
\hline
\end{tabular}

Table 7 shows the findings for the students' mathematics performance for both the STEM approach $(t=-5.889, \mathrm{df}=33, p<0.05)$ and conventional method $(t=-5.231, \mathrm{df}=33$, $p<0.05)$, including the post-test for the STEM approach and the conventional method $(t=3.048, \mathrm{df}=33, p<0.05)$ using the pre-test and post-test data. Based on the acquired data analysis results, the null hypothesis was rejected; this illustrated a significant difference in mathematics performance between students who participated in the STEM approach and the conventional method. Additionally, the mean score for the post-test performance was more impressive compared to the mean score of the pre-test performance for both learning methods. The mean score for performance also demonstrated that the duration of the treatment for the STEM approach and the conventional method was effective. Likewise, the mean score of the post-test STEM approach performance was higher and more impressive compared to the mean score of the post-test conventional method performance. 
Table 7. Analysis of mathematics performance for the STEM approach and conventional method.

\begin{tabular}{|c|c|c|c|c|c|c|c|}
\hline \multirow{2}{*}{\multicolumn{2}{|c|}{ Score Differences Pair }} & \multicolumn{3}{|c|}{ Paired Differences } & \multirow[b]{2}{*}{$t$} & \multirow[b]{2}{*}{$\mathrm{df}$} & \multirow[b]{2}{*}{$\begin{array}{c}\text { Sig. } \\
\text { (2-Tailed) }\end{array}$} \\
\hline & & Mean & $\begin{array}{c}\text { Std. } \\
\text { Deviation }\end{array}$ & Std. Error Mean & & & \\
\hline Pair 1 & $\begin{array}{c}\text { Pre-test-Post- } \\
\text { test } \\
(\mathrm{STEM})\end{array}$ & -17.059 & 16.892 & 2.897 & -5.889 & 33 & 0.000 \\
\hline Pair 2 & $\begin{array}{c}\text { Pre-test-Post- } \\
\text { test } \\
\text { (conventional) }\end{array}$ & -9.088 & 10.131 & 1.737 & -5.231 & 33 & 0.000 \\
\hline Pair 3 & $\begin{array}{c}\text { Post-test-Post- } \\
\text { test } \\
\text { (STEM- } \\
\text { conventional) }\end{array}$ & 16.794 & 32.132 & 5.511 & 3.048 & 33 & 0.005 \\
\hline
\end{tabular}

Note: $\mathrm{df}-$ degree of freedom.

According to Gignac and Szodorai [41], the effect size can be used to test the associations between variables. The three interpretive categories for associations using the formula of Cohen's $d$ are large $(d=0.80)$, moderate $(d=0.50)$, and small $(d=0.20)$ [42]. As for the paired sample $t$-test, the effect size (d) was calculated using the formula of Cohen's $d$, that is, the mean difference is divided by the standard deviation difference. The effect size for the STEM approach and the conventional method post-tests was recorded at $d=0.53$. This indicates that the use of the STEM approach had a better effect than the conventional method. Hence, there was a significant and moderate difference in mathematics performance between the students who participated in the STEM approach and the conventional method.

This study was conducted to examine the effectiveness of the STEM approach in the teaching and learning of mathematics, particularly in the three-dimensional geometric shapes topic to increase the performance level of the research samples. The first objective examined in this study was related to student attitudes towards the STEM approach for this topic and the findings revealed that student attitudes towards the STEM approach were at a moderate level. This was supported by Sahin and Top [11], who evidenced that student attitudes towards the STEM approach have a significant relationship. Additionally, a study by Nadelson and Seifert [16] showed that the STEM approach can motivate students to think positively and produce a good outcome through STEM-based learning. Furthermore, Lin et al. [10] also found that the teaching and learning process through the STEM approach leads to a positive student attitude. Overall, based on the findings and support from previous studies, it can be deduced that student attitudes towards the STEM approach were positive and impressive.

The second objective addresses the differences in mathematics performance between students who participated in the STEM approach and the conventional method through a pre-test and post-test. The data analysis results showed a significant difference between mathematics performance scores between the students who participated in the STEM approach and the conventional method in the pre-test and post-test. However, students who participated in the STEM approach performed better than those in the conventional learning method in the post-test because the mean score for the STEM approach performance was higher than the mean score for the conventional method performance. This finding was supported by Bicer at al. [21], who evidenced that the students participating in STEM-based learning performed better compared to the students who participated in the conventional learning method. Moreover, based on a study by Afriana et al. [22], the STEM approach can attract student attention, interest, and motivation. LaForce et al. [2] also showed that the STEM approach can inculcate interest and produce a positive student attitude towards learning. Therefore, in the present study, students' mathematics performance scores through the STEM approach are better than those who participated in the conventional method. 


\section{Limitations and Future Research}

Several limitations to this pilot study need to be acknowledged. The limitations are the selection of the sample size with non-probability sampling and cannot be generalised. The time constraint in treatment duration was limited to only a week because of the COVID-19 outbreak, which resulted in schools being closed and students pursuing online learning. Future researchers can provide a longer treatment duration, perform a comparative study based on the gender of participants, and increase the number of research samples to widen the research context. The ultimate treatment duration for students to pursue and successfully acquire knowledge is greater than or equal to two weeks.

\section{Conclusions}

STEM is an interdisciplinary combination of science, technology, engineering, and mathematics that leads to changes in the education system by implementing STEM elements in the teaching and learning process. This has also brought about changes in the educational curriculum, such as at the secondary school level from the Integrated Curriculum for Secondary Schools (KBSM) to the Standard Curriculum for Secondary Schools (KSSM). As a result, this enables early exposure to technology and engineering fields among students through the science and mathematics subjects. Hence, this study was conducted to examine the effectiveness of the STEM approach in helping students improve their mathematics performance. The results from this study have shown that the learning method through the STEM approach is more effective than the conventional method because the performance scores of the students who participated in the STEM approach were evidently better than the performance scores of the students who participated in the conventional method. This result supports the social constructivism theory that mentioned learning using the inquiry process. The mathematics performance scores increased based on the exploration of gaining knowledge through interaction, even though the teaching and learning process was limited due to COVID-19. In accordance with behaviourism theory, this result showed that the students' behaviour tended to be more positive as a result of learning mathematics using the STEM approach.

Since the limitations in this study included a small sample size of only 68 students and a short treatment duration, improvements should be adapted in the future by extending the treatment duration and increasing the number of respondents to broaden the research context. Researchers can also work with other researchers to broaden this context by increasing the number of research samples to obtain more accurate analysis results. Furthermore, future researchers can add more variables by examining student interest and motivation towards the implementation of STEM in the teaching and learning process.

Nonetheless, the implication of this study to the social constructivism theory lies in terms of how the teaching and learning process was handled while carrying out group activities. Due to the spread of COVID-19, social distancing is now highly emphasised in learning activities and this hinders students from completing group assignments on time. Consequently, it takes longer for the students to complete the assigned tasks. Meanwhile, in terms of the sampling methodology, this study could not use the quasi-experimental random sampling technique because the research samples were assigned according to classes and the researchers could only divide and distribute the students into two groups. Thus, it is suggested that future researchers use the random sampling technique to select the research samples to involve more students with different achievement levels and be able to generalise the results. A comparative study based on the gender of the participants can also yield great potential to demonstrate the pattern of mathematics performance in different settings or contexts. For advancement in the knowledge of STEM education or mathematics education, this study offers some important impactful insights into the exploration of the new style of pedagogy in teaching and learning different topics in mathematics. This will encourage researchers to modify teaching approaches with the different topics of mathematics. The findings also empirically help to address the potential STEM approach, which involves both inquiry-based learning and problem-based learning, in terms of 
improving the mathematics students' academic performance regarding three-dimensional geometric shapes.

Author Contributions: Conceptualization, S.F.K.; data curation, S.F.K.; formal analysis, M.E.E.M.M.; funding acquisition, M.E.E.M.M.; investigation, S.F.K.; methodology, S.F.K.; project administration, S.F.K.; supervision, M.E.E.M.M.; validation, M.E.E.M.M.; writing—original draft, S.F.K.; writing—review and editing, M.E.E.M.M. All authors have read and agreed to the published version of the manuscript.

Funding: This research was funded by the Ministry of Higher Education (MOHE), Malaysia, through the Fundamental Research Grant Scheme (FRGS) (FRGS/1/2018/SSI09/UKM/02/1) and Faculty of Education, Universiti Kebangsaan Malaysia (UKM).

Institutional Review Board Statement: This study was conducted according to the guidelines of the Declaration of Helsinki and approved by the Institutional Review Board of St. Joseph's Private Secondary School, Kuching, Sarawak, Malaysia [UKM/FND/SKG/P99986], approved on 24 July 2020.

Informed Consent Statement: Informed consent was obtained from all subjects involved in the study.

Data Availability Statement: The data presented in this study are available on request from the corresponding author.

Acknowledgments: The authors would like to thank the anonymous reviewers for their valuable comments and suggestions regarding improving the content, quality, and presentation of this paper.

Conflicts of Interest: The authors declare no potential conflicts of interest regarding the research, authorship, and/or publication of this article.

\section{Appendix A}

Table A1. Students' Attitude towards STEM Approach Questionnaire. Reprinted with permission from ref. [33]. Copyright 2016 Nadi Suprapto.

\begin{tabular}{cr}
\hline Code & Items \\
\hline S & Science \\
S1 & I know I can do well in science. \\
S2 & I expect to use science when I finish my study. \\
S3 & Knowing science will help me earn a living. \\
S4 & Science will be important to me in my working life. \\
S5 & I will need science for my future work. \\
S6 & I would consider a career in science. \\
M & Mathematics \\
M1 & I enjoy learning mathematics. \\
M2 & I am good at mathematics. \\
M3 & I am the type of student who does well in mathematics. \\
M4 & I am sure I could do advanced work in mathematics. \\
M5 & I can get good grades in mathematics. \\
M6 & I would consider choosing a career that uses mathematics. \\
TE & Technology and Engineering \\
\hline TE1 & I enjoy learning by using technology. \\
TE2 & If I learn engineering, then I can improve things that people use every day. \\
TE3 & I am curious about how electronics work. \\
TE4 & I am interested in what makes machines work. \\
TE5 & I like to imagine creating new products. \\
TE6 & I believe I can be successful in a career in engineering. \\
\hline
\end{tabular}


Table A1. Cont.

\begin{tabular}{|c|c|}
\hline STEM & Science, Technology, Engineering, and Mathematics \\
\hline STEM1 & I would like to use creativity and innovation in my future work. \\
\hline STEM2 & To learn engineering, I have to be good at science and mathematics. \\
\hline STEM3 & $\begin{array}{c}\text { Knowing how to use mathematics and science together will allow me to invent } \\
\text { useful things. }\end{array}$ \\
\hline STEM4 & Science, technology, engineering, and mathematics make our lives better. \\
\hline STEM5 & Science, technology, engineering, and mathematics are very important in life. \\
\hline STEM6 & $\begin{array}{l}\text { Science, technology, engineering, and mathematics are good for the future of } \\
\text { our country. }\end{array}$ \\
\hline STEM7 & $\begin{array}{c}\text { I would like to have a job that involves science, mathematics, engineering, } \\
\text { or technology. }\end{array}$ \\
\hline
\end{tabular}

\section{References}

1. Loh, S.L.; Pang, V.; Lajium, D. A Case study of teachers' pedagogical content knowledge in the implementation of integrated STEM education. J. Pendidik. Sains Mat. Malays. 2020, 10, 49-64.

2. LaForce, M.; Noble, E.; Blackwell, C. Problem-Based Learning (PBL) and Student Interest in STEM Careers: The Roles of Motivation and Ability Beliefs. Educ. Sci. 2017, 7, 92. [CrossRef]

3. Dutta, S. Conventional Teaching in Basic Science: An inner view. J. Med. 2010, 3, 246-250.

4. Huang, C.S.J.; Su, A.Y.S.; Yang, S.J.H.; Liou, H.H. A collaborative digital pen learning approach to improving students' learning achievement and motivation in mathematics courses. Comput. Educ. 2017, 107, 31-44. [CrossRef]

5. Ministry of Education Malaysia. Pelan Pembangunan Pendidikan Malaysia 2013-2025; Ministry of Education Malaysia: Putrajaya, Malaysia, 2013.

6. Fatah, A.; Suryadi, D.; Sabandar, J.; Turmudi. Open-ended approach: An effort in cultivating students' mathematical creative thinking ability and self-esteem in mathematics. J. Math. Educ. 2016, 7, 9-18. [CrossRef]

7. Ministry of Education Malaysia. Panduan Pelaksanaan Sains, Teknologi, Kejuruteraan dan Matematik (STEM) Dalam Pengajaran dan Pembelajaran; Ministry of Education Malaysia: Putrajaya, Malaysia, 2016. Available online: http://smksyedsira.edu.my/wpcontent/uploads/2016/12/7.-Panduan-Pelaksanaan-STEM-Dalam-PP.pdf (accessed on 6 October 2020).

8. Ugras, M. The Effects of STEM Activities on STEM Attitudes, Scientific Creativity and Motivation Beliefs of the Students and Their Views on STEM Education. Int. Online J. Educ. Sci. 2018, 10, 165-182. [CrossRef]

9. Wahono, B.; Lin, P.L.; Chang, C.Y. Evidence of STEM Enactment Effectiveness in Asian Student Learning Outcomes. Int. J. STEM Educ. 2020, 7, 36. [CrossRef]

10. Lin, K.Y.; Hsiao, H.S.; Williams, P.J.; Chen, Y.H. Effects of 6E-oriented STEM practical activities in cultivating middle school students' attitudes toward technology and technological inquiry ability. Res. Sci. Technol. Educ. 2019, 38, 1. [CrossRef]

11. Sahin, A.; Top, N. STEM Students on the Stage (SOS): Promoting Student Voice and Choice in STEM Education through an Interdisciplinary, Standards-Focused, Project Based Learning Approach. J. STEM Educ. Innov. Res. 2015, 16, 24.

12. Maeda, J. STEM + Art = STEAM. STEAM J. 2013, 1, 34. [CrossRef]

13. Edy Hafizan, M.S.; Lilia, H.; Mohamad Sattar, R.; Kamisah, O.; Mohd Afendi, Z. STEM learning through engineering design: Impact on middle secondary students' interest towards STEM. Eurasia J. Math. Sci. Technol. Educ. 2017, 13, 1189-1211. [CrossRef]

14. Anggraini, F.I.; Huzaifah, S. Implementasi STEM dalam pembelajaran IPA di Sekolah Menengah Pertama. Pros. Semin. Nas. Pendidik. IPA 2017, 1, 722-731.

15. Wong, W.S.; Kamisah, O. Pembelajaran Berasaskan Permainan dalam Pendidikan STEM dan Penguasaan Kemahiran Abad Ke-21. Politek. Kolej Komuniti J. Soc. Sci. Humanit. 2018, 3, 121-135.

16. Nadelson, L.S.; Seifert, A.L. Integrated STEM defined: Contexts, challenges, and the future. J. Educ. Res. 2017, 110, 221-223. [CrossRef]

17. English, L.D. Stem: Challenges and Opportunities for Mathematics Education. In Proceedings of the 39th Conference of the International Group for the Psychology of Mathematics Education, Hobart, Australia, 13-18 July 2015; pp. 4-18.

18. Kumar, K.; Chang, C.; Chang, C. The Impact of the Flipped Classroom on Mathematics Concept Learning. Int. Forum Educ. Technol. Soc. 2016, 19, 134-142.

19. Mohd Ayub, A.F.; Tarmizi, R.A.; Abu Bakar, K.; Luan, W.S. Adoption of WxMaxima software in the classroom: Effect on students' motivation and learning of mathematics. Malays. J. Math. Sci. 2014, 8, 311-323.

20. Minarni, A.; Napitupulu, E.E.; Husein, R. Mathematical Understanding and Representation Ability of Public Junior High School in North Sumatra. J. Math. Educ. 2016, 7, 43-56. [CrossRef]

21. Bicer, A.; Capraro, R.M.; Capraro, M.M.; Oner, T.; Boedeker, P. STEM Schools vs. Non-STEM Schools: Comparing Students' Mathematics Growth Rate on High-Stakes Test Performance. Int. J. New Trends Educ. Implic. 2015, 6, 138-150.

22. Afriana, J.; Permanasari, A.; Fitriani, A. Project based learning integrated to stem to enhance elementary school's students' scientific literacy. J. Pendidik. IPA Indones. 2016, 5, 261-267. [CrossRef] 
23. Capraro, R.M.; Capraro, M.M.; Scheurich, J.J.; Jones, M.; Morgan, J.; Huggins, K.S.; Corlu, M.S.; Younes, R.; Han, S. Impact of sustained professional development in STEM on outcome measures in a diverse urban district. J. Educ. Res. 2016, 109, 181-196. [CrossRef]

24. Han, S.; Yalvac, B.; Capraro, M.M.; Capraro, R.M. In-service teachers' implementation and understanding of STEM project-based learning. Eurasia J. Math. Sci. Technol. Educ. 2015, 11, 63-76. [CrossRef]

25. Ardianti, S.; Sulisworo, D.; Pramudya, Y.; Raharjo, W. The Impact of the Use of STEM Education Approach on the Blended Learning to Improve Student's Critical Thinking Skills. Univers. J. Educ. Res. 2020, 8, 24-32. [CrossRef]

26. Seshaiyer, P.; Sun, J.; Peixoto, N.; Long, M.; Corcoran, M.; Grewal, V. Inquiry-based approaches in K-12 classrooms to empower the next generation STEM workforce. In Proceedings of the Frontiers in Education Conference, FIE 2014, Madrid, Spain, 22-25 October 2014; pp. 3-10. [CrossRef]

27. Ramli, N. Keberkesanan Pembelajaran Koperatif Model Students Teams-Achievement Divisions (STAD) Dalam Fizik Terhadap Pencapaian Pelajar. Master's Thesis, Universiti Tun Hussein Onn Malaysia, Johor, Malaysia, 2016.

28. Wan Nor Fadzilah, W.H.; Nurazidawati, M.A.; Oziah, O.; Lilia, H.; Mohamad Sattar, R.; Kamisah, O.; Zanaton, I. Fostering Students' 21st Century Skills through Project Oriented Problem Based Learning (POPBL) in Integrated STEM Education Program. Asia-Pac. Forum Sci. Learn. Teach. 2016, 17, 3. Available online: https://www.eduhk.hk/apfslt/download/v17_issue1_files/ fadzilah.pdf (accessed on 16 November 2020).

29. Thibaut, L.; Ceuppens, S.; De Loof, H.; De Meester, J.; Goovaerts, L.; Struyf, A.; Boeve-de Pauw, J.; Dehaene, W.; Deprez, J.; De Cock, M.; et al. Integrated STEM Education: A Systematic Review of Instructional Practices in Secondary Education. Eur. J. STEM Educ. 2018, 3, 2. [CrossRef]

30. McKinley, J. Critical Argument and Writer Identity: Social Constructivism as a Theoretical Framework for EFL Academic Writing Crit. Inq. Lang. Stud. 2015, 12, 184-207. [CrossRef]

31. Vygotsky, L.S. Mind in Society: The Development of Higher Psychological Processes; Harvard University: Cambridge, MA, USA, 1979.

32. Dilshad, M.N. Learning Theories: Behaviorism, Cognitivism, Constructivism. Int. Educ. Res. J. 2017, 3, 64-66.

33. Suprapto, N. Students' attitudes towards STEM education: Voices from Indonesian junior high schools. J. Turk. Sci. Educ. 2016, 13, 75-87. [CrossRef]

34. Creswell, J.W. Educational Research Planning, Conducting and Evaluating Quantitative and Qualitative Research, 4th ed.; Pearson Education, Inc.: Boston, MA, USA, 2012.

35. Etikan, I.; Musa, S.A.; Alkassim, R.S. Comparison of Convenience Sampling and Purposive Sampling. Am. J. Theor. Appl. Stat. 2016, 5, 1-4. [CrossRef]

36. Kumar, R. Research Methodology a Step-By-Step Guide for Beginners; SAGE Publications Ltd.: Delhi, India, 2012.

37. Vinet, L.; Zhedanov, A. A "missing" family of classical orthogonal polynomials. J. Phys. A Math. Theor. $2011,44,085201$. [CrossRef]

38. Cronbach, L.J. Coefficient alpha and the internal structure of tests. Psychometrika 1951, 16, 297-334. [CrossRef]

39. Love, B.; Hodge, A.; Grandgenett, N.; Swift, A.W. Student learning and perceptions in a flipped linear algebra course. Int. J. Math. Educ. Sci. Technol. 2014, 45, 317-324. [CrossRef]

40. Layang, F.A.; Mahamod, Z. Tahap Pengetahuan, Kesediaan dan Sikap Guru Bahasa Melayu Sekolah Rendah dalam Melaksanakan Pengajaran dan Pembelajaran Peta Pemikiran i-Think. J. Pendidik. Malays. 2019, 44, 37-44.

41. Gignac, G.E.; Szodorai, E.T. Effect size guidelines for individual differences researchers. Personal. Individ. Differ. 2017, 102, 74-78. [CrossRef]

42. Navarro, D.J. Learning Statistics with R: A Tutorial for Psychology Students and Other Beginners; University of Adelaide: Adelaide, Australia, 2015. Available online: https:/ /www.fon.hum.uva.nl/paul/lot2015/Navarro2014.pdf (accessed on 20 November 2020). 